\title{
Energy variations in apartment buildings due to different shape factors and relative size of common areas
}

\author{
I. Danielski* \\ Mid Sweden University, Östersund, Sweden \\ *Corresponding author. Tel: +46 (0)63 5416, Fax: +46 (0)63 165500, E-mail: itai.danielski@miun.se
}

\begin{abstract}
A multi-storey residential building includes different sub areas, for example: apartment areas and common areas (corridors, basements, attic etc.). Each sub area may have different specific final energy use. Areas with lower specific final energy use will have a relatively lower contribution to total final energy use of a building. Examples of areas with low specific final energy use are corridors, basement and attics. All these areas are included in the calculation of a building's total final energy use. As a result, there is a risk that buildings designers may fulfill stricter end-use energy requirements simply by constructing buildings with larger areas containing a lower specific final energy use. In addition, the envelope area of the building may vary for a given floor area depending on the shape factor of the building. The heat losses of a building depend on the envelope area, the area that is in direct contact outdoor environment. Thus, buildings with a lower shape factor will have lower heat losses and hence a lower specific final energy use.
\end{abstract}

In this paper, we study the impact of those two factors on the specific final energy use of similar constructed apartment buildings in Stockholm. We consider 22 multi-storey residential buildings in ten locations that were built in accordance with the Stockholm program for environmental adapted buildings. They were chosen since they have different ratio of common area to total heated area and large variation in specific final energy use. Other characteristics such as energy systems, construction properties and population density were similar.

The analyses showed a high correlation between the shape factor of the buildings and their specific final energy use. An increased shape factor of a building by 0.1 increased the specific final energy use by $5.3 \mathrm{kWh} / \mathrm{m}^{2}$. The specific final energy use of the studied buildings could vary up to $30 \mathrm{kWh} / \mathrm{m}^{2}$ only because of the shape factor. Therefore it is recommended that the shape factor is considered in building codes for new buildings especially in cold climates. The energy simulations showed that the specific final energy use in the common areas was about $75 \%$ lower than in apartment areas. Hence, including larger common areas in the design of new apartment buildings reduce the specific final energy use significantly while the final energy use per resident will increase. This needs to be considered in energy requirements of buildings. Normalizing the final energy use by the apartment area should be considered as alternative method as it reduces variations in specific final energy use due to the relative size of common areas and increases the quality of using the SFEU for energy requirements.

Keywords: Specific final energy use, Shape factor, Surface area to volume ratio, Energy variation.

\section{Nomenclature}

SF Shape factor..........................m ${ }^{-1}$

SFEU Specific final energy use... $\mathrm{kWh} / \mathrm{m}^{2}$, a

VHR Ventilation Heat Recovery

\section{Introduction}

Several programs have been launched in Sweden with the aim of improving the energy efficiency of new buildings. One example is the Stockholm program for environmental adapted buildings [1], which aims to stimulate the construction of buildings with final energy use lower than required by the Swedish building code. The Stockholm program covers apartment buildings constructed between 1997 and 2005, and requires certain limits for the final energy use as listed in Table 1 
Table 1. Final energy requirements for the SFEU and final electricity use in $\mathrm{kWh} / \mathrm{m} 2$,a.

\begin{tabular}{lcc}
\hline Type of heating system & Total final energy use & Maximum final electricity use \\
\hline District heating & 140 & 50 \\
District heating with ventilation & 125 & 60 \\
heat recovery (VHR) & 90 & 90 \\
Electric resistance heaters & & \\
\hline
\end{tabular}

Since the lunch of the Stockholm program, new apartment buildings were built in 77 different locations within the Stockholm municipality. All of these buildings were built in accordance with the program's specifications, yet only $35 \%$ of the locations fulfil the final energy use requirements. In addition, the SFEU vary widely between different locations (Fig. 1). In this study, we analyzed the variations in SFEU due to the surface-area-to-volume ratio of apartment buildings (henceforth shape factor) and the relative size of the common area.

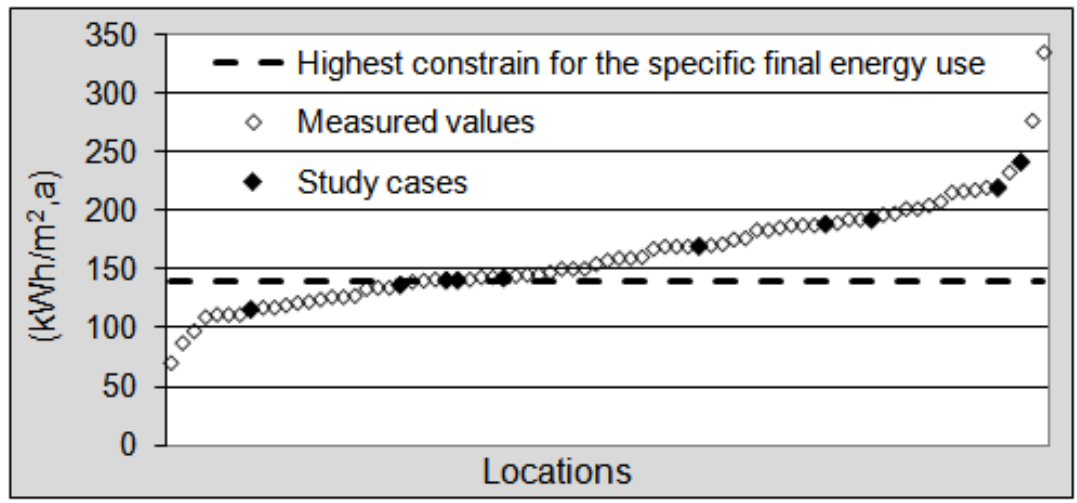

Fig. 1. The SFEU of new apartment buildings built in 77 locations that participated in the Stockholm program. The black points represent the study cases in this study.

\subsection{The shape factor (SF)}

The shape factor (SF) of a building is its surface-area-to-volume ratio and is a measure of a building's compactness. Buildings with a higher SF are less compact and therefore have a larger surface area for a given building's volume. The surface area of a building is the boundary between heated spaces and unheated spaces, and accounted for large percentage of the heat losses in buildings. Depecker et al. [2] showed that in colder climates the correlation between the final energy use and the SF is strong. Buildings with a higher value of SF have a higher final energy use. China has integrated the SF of buildings into its design standard for energy efficiency of public buildings, which applies stricter values for new buildings in colder climates [3]. Sweden is located in cold climate and the impact of the SF on the final energy use is expected to be significant.

\subsection{The specific final energy use}

The SFEU, i.e. the final energy use per unit of floor area, is used to compare final energy use in buildings with different sizes, and it is affected by how the floor area size is calculated. According to CEN [4], the floor area of a building can vary by $20 \%$ depending on the measurement method. In Sweden, the area that is used for calculating the specific final energy use in buildings is defined by the National Board of Housing, Building and Planning [5] and is measured according to standard SS 021053 [6]. The area definition is equivalent to the European "overall internal dimension" [4] with a few differences: it excludes unheated areas and adjacent garages. An unheated area is defined as an area with temperature lower then $10^{\circ} \mathrm{C}$ during the heating season. This is due to the low energy contribution of unheated areas 
or adjacent garages relative to the relative increase in floor area. Including these areas will result in lower SFEU values [7] without increasing the building's energy efficiency.

The heated floor area in apartment buildings that agrees with the above Swedish definition is not homogeneous and includes different sub-areas including apartments, corridors and basements. The SFEU of apartment building is an average of the SFEU of its different sub areas. Each of these sub-areas has its own functionality and energy characteristics that determine its contribution to the average SFEU of the building. Designing new buildings with relative large sub-areas with low SFEU, for example due to lower temperatures, can reduce the value of the average SFEU of the building.

In this study, we distinguish between apartment areas and common areas. The common areas including: corridors, basements, attics and all other heated areas that are not part of the apartments. We do not consider buildings with integrated areas for commercial purposes, e.g. offices and small shops. Our hypothesis is that the SFEU in the common areas is lower than that in the apartment areas. Thus, the relative size of the common area (common-area-to-totalfloor-area ratio) will affect the average SFEU of the building. The reasons for the low SFEU in the common areas are discussed below in the Swedish context.

In Sweden, the indoor temperature in the apartment areas should satisfy the minimum thermal comfort conditions. According to ASHRAE, the comfort zone for the operative temperature is between $20^{\circ} \mathrm{C}$ and $25^{\circ} \mathrm{C}$ [8]. In common areas $18^{\circ} \mathrm{C}$, can be used to reduce heating costs [5]. Hence the temperature in common areas can be a few degrees lower than in apartment areas.

The energy used for domestic water heating is also higher in the apartment areas. Households in Sweden use $1200 \mathrm{kWh} /$ person, a on average [9]. In common areas, the use of hot water and energy for water heating is negligible. Here we argue that the energy use by central laundry machine located in the common areas should be allocated to the apartment areas. The amount of energy used can be related to the number of residents and therefore to the total size of the apartments' area. Increasing the common area size will not increase the energy use for laundry. It does not matter if the laundry is made in each apartment or in a cen tral laundry room. This argument can be apply to other apparatus that use energy in the common areas for example elevators.

Common areas have a lower windows-area-to-floor-area ratio than the apartment areas because of the natural light requirements in areas that residents visit often. Basements and attics may not have windows at all, whereas corridors that are surrounded by apartments have fewer windows per façade area in comparison with apartment's façade. Due to the higher Uvalues of windows in comparison with walls, the average U-value of the façade that is in contact with the common area is lower.

The minimum requirement for the ventilation flow-rate in apartment areas is 0.35 litter $/ \mathrm{sec}, \mathrm{m}^{2}$ [5]. In common areas it is possible to reduce the ventilation flow-rate to 0.1 litter $/ \mathrm{sec}, \mathrm{m}^{2}$ because of the low occupancy, which reduces ventilation heat losses.

\section{Methodology}

Twenty-two buildings built in 10 locations out of the 77 locations that participated in the Stockholm program were chosen for an in-depth analysis. These buildings have no commercial areas, i.e. offices and small shops, but large variations in SFEU (Fig. 1) despite similar constructions and energy supply systems. Each location consisted of one or several 
apartment buildings with at least three floors. All of the buildings have concrete foundations and use forced ventilation with fresh air entering through special openings in the façade, located under the windows and behind the radiators. In one location, ventilation heat recovery (VHR) using a heat pump was installed. All of the buildings were connected to the district heating network. The final energy use was measured during 2006 by Fortum-Värme, which is the energy supplier company in Stockholm. The areas in each building were measured manually using the architectural drawings of the buildings. For energy simulations we used the VIP Energy, which is a commercial dynamic energy balance simulation program that calculates the energy performance of buildings using real climate data. It was validated by IEA-BESTEST, ASHRAE-BESTEST and CEN-15265 [10].

\subsection{The shape factor (SF)}

The final energy use of the case-study buildings was compared to a final energy use of hypothetical reference buildings with similar sizes for volume, floor area sizes, ground floor, roof and windows-to-façade-area ratio but with SF of 1. To meet the lower SF the reference buildings need to be more compact with lower façade area size as illustrated in Fig. 2. The differences in final energy use assume to be related only to the smaller façade area of the reference buildings. Heat losses due to resident behaviour and ventilation heat losses assume to remain constant because of the similar volume and floor area size.

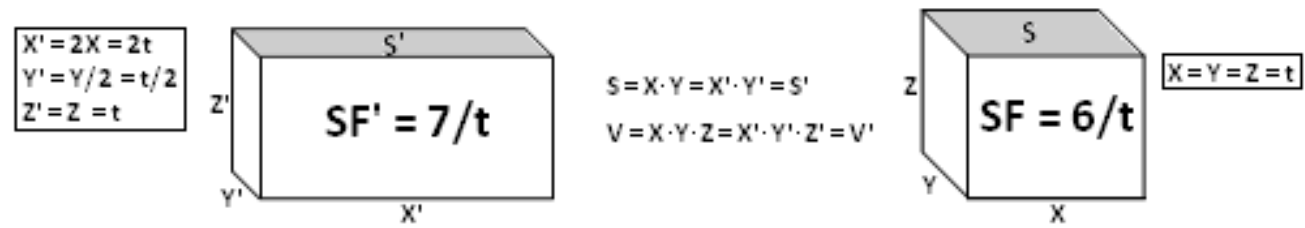

Fig. 2. Two buildings with similar volume, floor area, ground floor area, roof area and different SF.

The difference in final energy use between each case-study building and its reference buildings $(\Delta \mathrm{E})$ was calculated according to Eq. (1). Where $\Delta \mathrm{A}_{\text {Wall }}$ and $\Delta \mathrm{A}_{\text {Win }}$ are the area differences of wall and windows respectively between the case-study building and its reference buildings. $E_{W a l l}$ and $E_{W i n}$ are the difference in heat losses through $1 \mathrm{~m}^{2}$ of walls and windows respectively between the case-study building and its reference buildings. $\Delta \mathrm{A}_{\text {Wall }}$ and $\Delta \mathrm{A}_{\text {Win }}$ were calculated from the difference in SF and assuming constant windows-to-façadearea ratio. $E_{\text {Wall }}$ and $E_{\text {Win }}$ were calculated by the VIP Energy simulation program [10] assuming similar values for all the buildings. The volume of the building is equivalent to the floor area multiplied with the floor height, which is 2.7 meters for all the case-study buildings. Therefore we defined the SF as the surface-area-to-floor-area ratio instead of volume.

$$
\Delta \mathrm{E}=\Delta \mathrm{A}_{\mathrm{Wall}} \times \mathrm{E}_{\mathrm{Wall}}+\Delta \mathrm{A}_{\mathrm{Win}} \times \mathrm{E}_{\mathrm{Win}}
$$

\subsection{The relative size of the common area}

To determine how the relative size of the common area affects the SFEU of the buildings, five energy simulations were conducted. The following parameters were kept constant to reduce the influence of other factors: 1) the total floor area of the building; 2) the ratio of the glazed area to the floor area: $13 \%$ for the common areas and $22 \%$ for the apartment areas; and 3 ) the ratio of the apartment floor-area to the apartment façade-area. In each additional simulation, $75 \mathrm{~m}^{2}$ of floor-area and $66.8 \mathrm{~m}^{2}$ of façade area were allocated from the apartment area to the common area, which increased the relative size of the common area by $5 \%$ as listed in Table 2. The allocated areas were taken from the first floor in all simulations until the entire first 
floor was used as a common area. Parameters with values that differ between the apartment areas and common areas are listed in Table 3.

Table 2. Area sizes for each energy simulation. The first value relates to the apartment area and the second to the common area.

\begin{tabular}{ccccccc}
\hline & $\begin{array}{c}\text { Common area/ } \\
\text { Total floor area }\end{array}$ & $\begin{array}{c}\text { Floor area } \\
(\mathrm{m} 2)\end{array}$ & $\begin{array}{c}\text { Wall area } \\
(\mathrm{m} 2)\end{array}$ & $\begin{array}{c}\text { Glazed } \\
\text { area }(\mathrm{m} 2)\end{array}$ & $\begin{array}{c}\text { Roof } \\
(\mathrm{m} 2)\end{array}$ & $\begin{array}{c}\text { Ground floor } \\
\text { area }(\mathrm{m} 2)\end{array}$ \\
\hline 1 & 0.1 & $1475 / 163$ & $805 / 7$ & $472 / 21$ & $404 / 24$ & $376 / 52$ \\
2 & 0.15 & $1392 / 246$ & $771 / 57$ & $450 / 28$ & $404 / 24$ & $266 / 162$ \\
3 & 0.2 & $1310 / 328$ & $733 / 116$ & $428 / 29$ & $404 / 24$ & $147 / 281$ \\
4 & 0.25 & $1229 / 409$ & $710 / 153$ & $405 / 38$ & $404 / 24$ & $73 / 355$
\end{tabular}

Table 3. Parameters related to energy use used in all energy simulations.

\begin{tabular}{llcc}
\hline \multicolumn{1}{c}{ Parameter } & & Apartment area & Common area \\
\hline Indoor temperature & $\left({ }^{\circ} \mathrm{C}\right)$ & 22 & 18 \\
Ventilation air flow & $($ litre/sec-m2) & 0.35 & 0.1 \\
Electricity use & $(\mathrm{W} / \mathrm{m} 2)$ & 5.4 & 2 \\
Energy use for domestic water heating & $(\mathrm{W} / \mathrm{m} 2)$ & 5.8 & 0 \\
Body heat from tenants & $(\mathrm{W} / \mathrm{m} 2)$ & 1 & 0 \\
\hline
\end{tabular}

The energy simulations were performed using the Stockholm's climate data and were done by the VIP Energy simulation program [10] for one of the study cases, with a total floor area of $1500 \mathrm{~m}^{2}$. The roof consists of two layers of asphalt-impregnated felt, on $25 \mathrm{~mm}$ polywood board, $300 \mathrm{~mm}$ mineral wool between wooden roof trusses, and $150 \mathrm{~mm}$ concrete, giving an overall U-value of $0.129 \mathrm{~W} / \mathrm{m}^{2}, \mathrm{~K}$. The external walls have a $\mathrm{U}$-value of $0.249 \mathrm{~W} / \mathrm{m}^{2}, \mathrm{~K}$ and consist of $8 \mathrm{~mm}$ of plaster, $150 \mathrm{~mm}$ of mineral wool between wooden studs and $150 \mathrm{~mm}$ of bricks. $25 \%$ of the façade made up of triple glazed windows and doors and has overall Uvalue of $1.2 \mathrm{~W} / \mathrm{m}^{2}, \mathrm{~K}$. The ground floor consists of $20 \mathrm{~mm}$ oak boarding on $180 \mathrm{~mm}$ concrete slab laid on $150 \mathrm{~mm}$ expanded polystyrene and $100 \mathrm{~mm}$ macadam, resulting in a U-value of $0.236 \mathrm{~W} / \mathrm{m}^{2}, \mathrm{~K}^{\circ}$.

The final energy use from each simulation was normalized by two different area definitions: 1) the total heated floor area of the building (the current used method) and 2) the total apartments' area. The two area definitions provide two sets of calculated SFEU values for each energy simulation. The energy simulation results were compared to the SFEU of the reference buildings $(\mathrm{SF}=1)$.

\section{Results}

\subsection{The shape factor (SF)}

A high correlation was found between the SF and the SFEU as illustrated by the trend line in Fig. 3. Buildings with the VHR system were excluded but should follow the trend line as well because they have similar construction properties as the buildings without VHR system. The specific final energy use of buildings with VHR system is clearly noticeable in and is roughly the vertical distance to the trend-line (arrow in Fig. 3). 


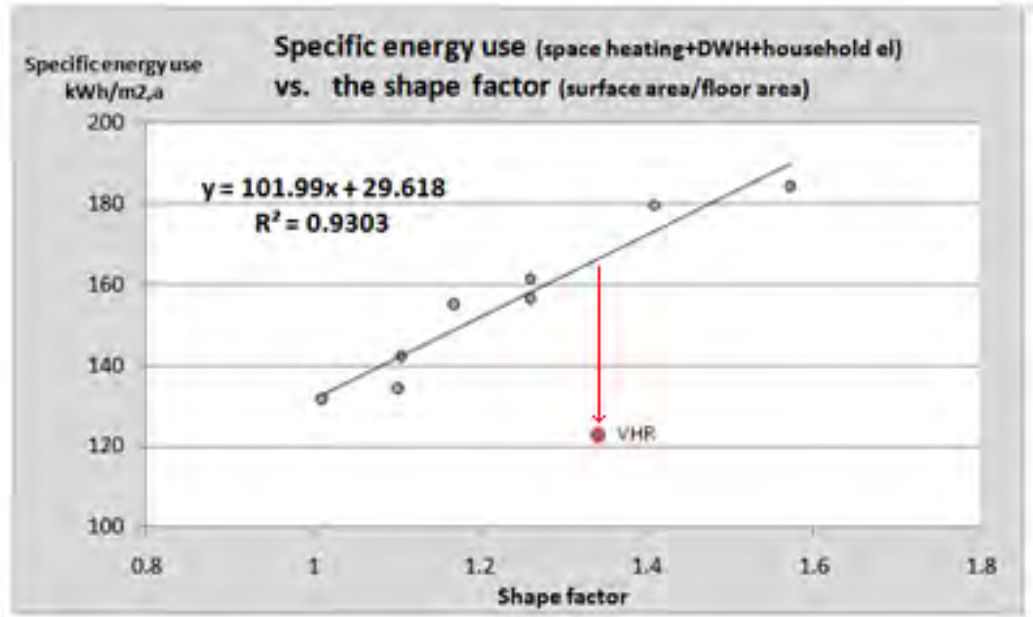

Fig. 3: A correlation between the SFEU and the shape factor of the building.

Fig.3 illustrates the difference in final energy use between each case-study building and its corresponding hypothetical case ( $\mathrm{SF}=1$ ). The SFEU is increasing by about $\sim 5.3 \mathrm{kWh} / \mathrm{m}^{2}$, a for each increase of 0.1 in the SF up to of $30 \mathrm{kWh} / \mathrm{m}^{2}$,a.

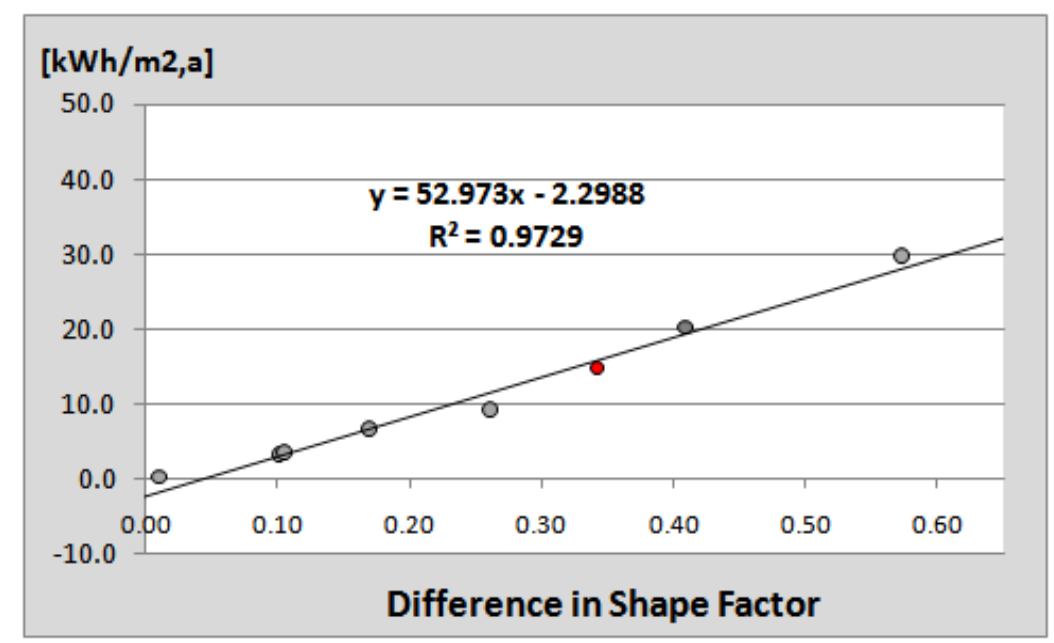

Fig. 4. SFEU losses (Y-Axis) in each study case due to difference in SF (X-axis).

\subsection{The relative size of the common area}

The SFEU of the buildings and the results from the energy simulations were calculated based on the total floor area (current used method) and the apartment area and plotted vs. the relative size of their common areas in Fig. 5. According to the energy simulation results, the SFEU in the common areas is about a quarter of the SFEU in the apartment areas. Increasing the relative size of the common area reduces the average SFEU of the building calculated by the current used method, although the SFEU in the apartment areas is nearly constant. When normalizing by the apartment area (new method) the average SFEU of the building slightly increases with increased common-area-to-floor-area ratio because the common area contributes more to the final energy (due to its increasing size), which is divided by smaller size of apartment area.

The trend of the specific final use of the study cases, calculated by the two methods, agrees with the simulation results (Fig. 5). Therefore, it is possible to conclude that the constant SFEU in the apartment areas calculated by the energy simulations valid for the study cases as well, and the variations in SFEU in Fig. $4\left(\sim 30 \mathrm{kWh} / \mathrm{m}^{2}\right.$, a) are only due to the differences in 
the relative size of areas with low SFEU (i.e. common areas). The variations reduced by half if applying the new method.

The savings in SFEU associated with the VHR system are clear, and are the vertical distance to the trend of the SFEU (arrows in Fig. 5 in both methods). However, the savings are questionable if comparing by the current method because the value of the SFEU use of the location with the VHR system is only slightly lower than values of other study cases.

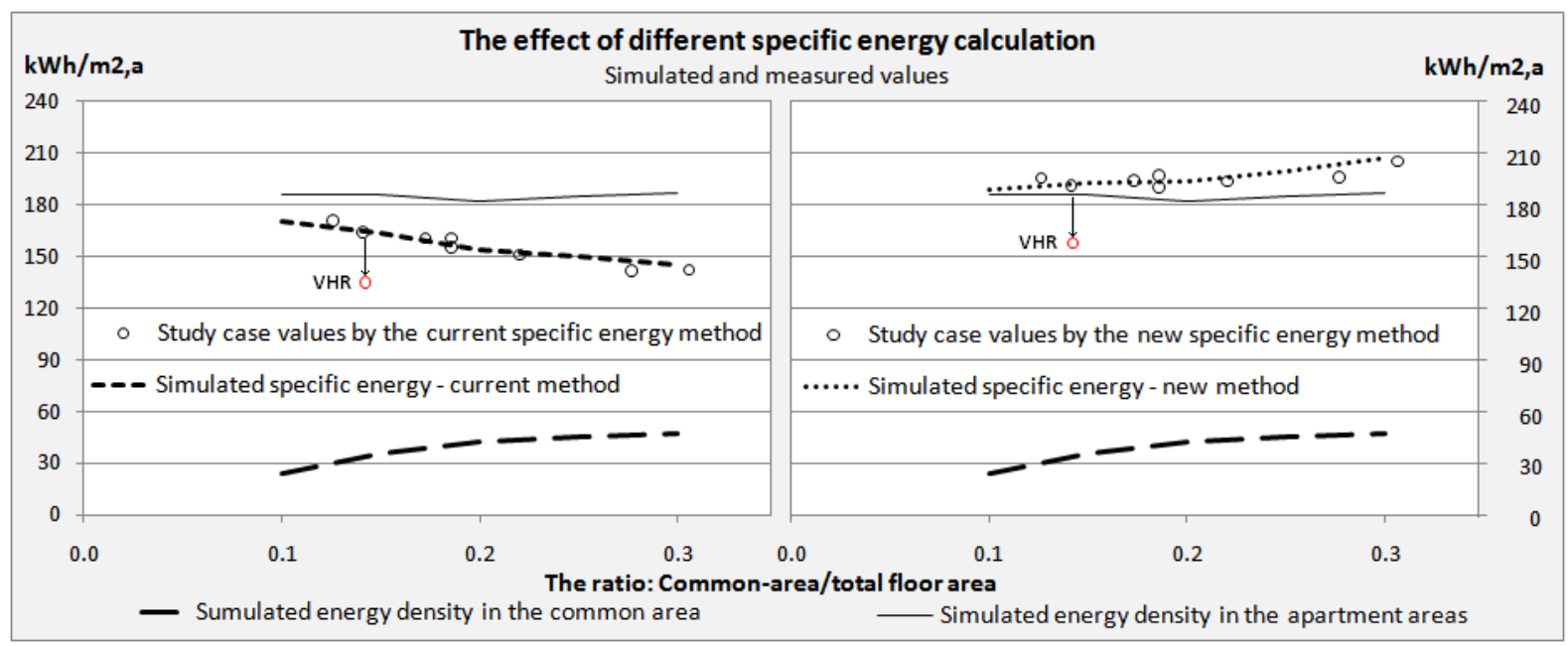

Fig. 5. The energy simulation results (lines) compared to the SFEU (circles) of the different study cases based on the total floor area (left diagram) and on the apartment area (right diagram).

\section{Discussion}

In this study we analysed the influence the shape factor (SF) of the building and the relative size of the common area, i.e. common-area-to-total-floor-area ratio, on the SFEU. Both parameters are together responsible for a variation in calculated SFEU of more than 50 $\mathrm{kWh} / \mathrm{m}^{2}$, a for the different case-study buildings. As a result reduction in SFEU use due to efficiency measures, as ventilation heat recovery, were not noticeable.

The SF has large effect on the building's final energy use. Buildings designed with large value of SF have larger surface area per floor and larger heat losses. As a result, larger heat losses exists and larger amount of energy is needed during the construction period. Therefore it is recommended that the shape factor is considered in building codes for new buildings especially in cold climates.

When calculating the SFEU based on the total floor area of the building (current used method) the SFEU of the building decrease as the relative size of the common area increases (i.e. corridors, basement, attics etc.) because the SFEU in the common areas is significantly lower than the SFEU in the apartment areas. In addition increasing the relative size of the common areas for a given total apartment's area will increase the final energy of the building because more common area needs to be heated. The final energy used in the common areas is used by the building's residents and the number of residence does not increase with increasing size of the common areas therefore the final energy use per residence will increase. Furthermore, increasing the relative size of the common area increases the building size per apartment area. Consequently, the energy use required to construct the building will increase per apartment area or alternatively per resident. As a result, designing buildings with larger relative size of common areas will reduce the average SFEU of the building, and stricter energy requirements could be achieved without implementing energy efficiency measures. However the final energy use per 
residence will increase. This needs to be considered in energy requirements of buildings. Normalizing the final energy use by the apartment area should be considered as alternative method because it reduces variations in SFEU due to the relative size of common areas and increases the quality of using the SFEU for energy requirements.

\section{References}

[1] The Stockholm municipality (2004) Program för Miljöanpassat byggande vid nybyggnad.

[2] Depecker, P., et al., Design of buildings shape and energetic consumption. Building and Environment, 2001. 36(5): p. 627-635.

[3] Yu, Z., S. Wang, and Y. Xie. Energy policy in public buildings -Challenges for China. 2007.

[4] CEN, Energy performance of buildings - Methods for expressing energy performance and for energy certification of buildings, in CEN/TC89, 2006.

[5] The Swedish Board of Housing Building and Planning, Building Regulations (BBR) in BFS 2006:22, Boverket, Editor. 2008, Boverket.

[6] SS 21054:2009, Area och volym för husbyggnader - Terminologi och mätregler. 2009, SIS.

[7] SOU 2005:67, Energideklarationer Metoder, utformning, register och expertkompetens. 2005, Statens Offentliga Utredningar: Stockholm.

[8] ASHRAE 55-2004, Thermal Environmental Conditions for Human Occupancy 2004.

[9] The Swedish Energy Agency. Vatten och varmvattenberedare. cited 2010; Available from: http://www.energimyndigheten.se

[10] Strusoft. VIP-Energy. Available from: www.strusoft.com. 